DOI: 10.25108/2304-1730-1749.iolr.2019.61.112-117

УдК 343.9

\title{
Means of achieving a goal of punishment
}

Abstract: Philosophy helps to solve a number of the most important problems, among of which, first of all, should be named the issues on the mental nature, on a level of psychic and a concept of man and personality. We should say with sorrow that currently jurisprudence uses not in full extent the results of these researches relating to an area of studying of the reasons of criminal behaviour of man. As for the research of the problems of mental impact of punishment on a man and mechanism of perception by a person of the threat, and also a holding role of punishment from illegal actions of a subject of activity, then they, practically, have never been an object of scientific consideration.

The threat of punishment deals, rather, with the psychology of people. Therefore, if psychologists were seriously interested in the impact of the threat of punishment on a person, this would lead to important practical results. This is to study the psychological regularities of the system "man threat of punishment". Only in this way we can understand the psychological attitude to this threat. Consideration of this issue requires a very brief form to turn to science - psychology, which studies the regularities and mechanisms of people's mental activity.

Keywords: punishment; goal and function; criminal sanction; psychology; reason of criminal behaviour; prevention.

From the moment the law comes into force, the threat of punishment acts as a means of prevention. Otherwise, punishment is only idle talk, meaning nothing, not defining, an abstract concept. Supporting the theory of dynamic criminal punishment, which was widely disseminated in Germany in the beginning of $20^{\text {th }}$ century, A.A. Korobeev, A.V. Uss and Yu.V. Golik make a conclusion that it (punishment) at the beginning works as faceless threat, then it is assigned to a specific person and finally executed [4, p. 157].

Thus, it turns that criminal-legal sanction practically does not play any role in prevention of criminal manifestations from the part of members of a society. In their opinion, "here, an instrument of influence on people's behaviour is an orienting informing, at least, simultaneously, in the two planes, a kind of guarantee-obligation that is given to all members of a society to fulfill the function on protection of appropriate social values, and from other hand - as a faceless threat that addressed to potential offenders of established prohibition" [4, p. 157]. At the same time, it is asserted the single meaningful function of punishment at this stage, i.e. at stage of criminal-legal sanction, is generally preventive one [4, p. 157]. However, if at this stage punishment fulfills the preventive task then it 'works', it acts as threat and correspondently acts as the means of achieving of set for a goal. Therefore, it is very important to understand the mechanism of psychological interaction of a man and criminal punishment. In other words, we should make clear how the criminal punishment influences to the members of society, and how a man perceives this threat psychologically. All this is

\footnotetext{
- Rahimov Ilham Mammadhasan oglu - Doctor of Juridical Sciences, Professor, Honoured Jurist of Azerbaijan Republic, Azerbaijan. E-mail: mopi_sid@yahoo.com
} 
necessary to strengthen an effectiveness of punishment's threat in order to keep people from commission of crimes. Maybe, indeed, the threat of punishment does not matter for abstaining people from criminal intentions? However, if it has, then in what extent? Why the humanity during its history is unable through criminal punishment to keep people from commission of illegal actions? Maybe, the matter is not only in punishment - as the most popular and expensive means of combating to crime? One thing is clear: no state has ever tried to abandon criminal punishment, although it has been proven that crime cannot be destroyed by this means. Unfortunately, we have not yet come up with a better one. Therefore, we should find the ways to increase an effectiveness of criminal punishment impact. At this we should keep in mind that we are talking about forcible measures but not the ways of social nature. The threat of punishment deals, rather, with the psychology of people. Therefore, if psychologists were seriously interested in the impact of the threat of punishment on a person, this would lead to important practical results. This is to study the psychological regularities of the system "man - threat of punishment". Only in this way we can understand the psychological attitude to this threat. Consideration of this issue requires a very brief form to turn to science - psychology, which studies the regularities and mechanisms of people's mental activity. Initially, psychology developed as an integral part of philosophy, and only in the middle of the $19^{\text {th }}$ century it separated in an independent science. Tugarinov V.P. noted: "Philosophy is a result, generalization of all preceding development of science and practice. Thus, the philosophy turns into the theoretical and ideological basis for all social sciences" [9, p. 98].

Philosophy helps to solve a number of the most important problems, among of which, first of all, should be named the issues on the mental nature, on a level of psychic and a concept of man and personality. We should say with sorrow that currently jurisprudence uses not in full extent the results of these researches relating to an area of studying of the reasons of criminal behaviour of man. As for the research of the problems of mental impact of punishment on a man and mechanism of perception by a person of the threat, and also a holding role of punishment from illegal actions of a subject of activity, then they, practically, have never been an object of scientific consideration. Certainly, one cannot fail to note that over the past 30 years the research in a field of legal psychology has a wide range. As it known, currently, there are quite widely and deeply studied such fields of legal psychology as forensic psychology, psychological grounds of preliminary investigation, psychology of judicial activity, correctional labour psychology etc. It appears that it comes the time to research and develop of general psychology in union with criminal law of scientific criteria and methods of the system "man-threat of punishment". This will help us to give scientifically substantiated recommendations to a lawmaker at constructing of criminal-legal sanction.

Punishment is a result of violation of established by the state appropriate criminal-legal norms that regulate the rules of people's behaviour. In criminal law this violation is named a crime. In the popular language, it can be said that the state has established certain rules for our behaviour, i.e., it has prohibited the commission of actions contrary to the interests of society and individuals. Thus, prohibition is the beginning of human interaction with punishment. Therefore, in the system "man is a threat of punishment" a special place belongs to the assessment of a person's ability to assimilate, to perceive the prohibition itself, because for recognizing it as capable of responsibility (to punishment) for violating the prohibition, i.e. established order, it is necessary to establish how generally it is capable to understand the regulatory role of basic values and norms of society. And for this, he must be able to access information about them, he must understand what is permitted and what is forbidden. And only after that a person is able to take into account their presence and make 
an appropriate decision: accept for leadership or reject in a situation of choice. In other words, a person who desires or intends to commit illegal deed must understand prohibitions, and also he will be able to assess the action and its consequences. At this, it is enough to assess an ability to adopt the norms and values that regulate of the behaviour in criminal-relevant situations and take into account at the choice of behaviour variant. Therefore, for the onset of responsibility, it is sufficient that a subject is aware of the harm of his deed and its consequences for others, violation by him the established criminal legal norms [8, p. 84].

Awareness of harmfulness of the consequences in case of encroaching on the goods of other person or interests of society has also the place at relatively low level of intelligence development. In this connection, Hegel's position is interesting, which considers as sufficient the ability to foresee the necessary consequences of the selective variant of behaviour for punishment, since only their "conduct" can be blamed. Moreover, one must realize the "universal quality" of the deed, i.e. to be able to correlate it with the guidelines set by society, which also should be "known" [6, $\mathrm{p}$. 245-249].

Legal science traditionally proceeds from the fact that punishment involves the recognition of both actual and legal signs of a criminally punished offense. This approach also corresponds to the general theoretical characterization of law, as an instrument for regulating social relations, which must pass through the consciousness and will of people. The idea of V.P. Salnikov seems to be successful about the fact that it is enough to focus on the moral standards that underlie in the basis of the principles of law, in particular, on the basic legal concepts, such as, for example, a "crime" expressing these principles [7, p. 46-47]. This gives an opportunity to make a decision about legal or illegal behaviour in the terms of absence of information on specific legal norm, basing on understanding the general directness of legislation, its functions, expressing of moral requirements in it. Prohibition words are followed by punishment words. What this means is understood by every normal person. While the prohibition allows desire to be aroused, words about punishment should allow the awakening to terrible imagination. "And the Lord God commanded the man, "You are free to eat from any tree in the garden; but you must not eat from the tree of the knowledge of good and evil, for when you eat from it you will certainly die" (Genesis 2.16-17). What it means to die, Adam, of course, did not understand at all, however, assuming that he was told this, his misunderstanding does not prevent him from getting the idea of the terrible. In this regard, even an animal is able to understand the facial expression and shades of the voice of a speaking person without understanding the words themselves. When committing a sin, Adam understood that he was breaking the ban, i.e. "God's Law", and that for this he will be punished. However, he could not restrain himself. On the one hand, the prohibition arouses desire in him, and on the other, he fears, since the prohibition awakens the possibility of freedom in him. That is why the nature of original sin should be explained through the category of fear, which is the content of any punishment. The threat of exposure to people gives rise to fear of punishment and thereby prevents in many cases from committing crimes. This fear arises even before the consequences of their illegal acts, as a result of which punishment may occur. Professor of the Harvard University V. Kennon, already in 1927, while studying the physiology of emotions, came to the conclusion that "fear, rage, pain and hunger pangs are elementary feelings that rightly belong to the most powerful factors that determine the behavior of humans and animals" [3, p. 15].

Fear arises already at the moment of the awakening of the desire to commit a crime, for it is from this moment that the instinct of self-preservation appears, on which fear rests. This testifies 
that fear is an internal state caused by a threatening real or perceived disaster. Fear is, as psychologists say, the desire for what you fear, it is sympathetic antipathy. A person violates the law, desiring this, but is at the same time afraid, because he remembers that punishment is provided for this. Fear is an alien force that captures the individual, and yet he cannot be freed from it, and does not want to, because a person is afraid, but afraid of what he wants. That is why all potential criminals have a sense of fear. This concerns also the person who committed reiterated crimes, to recidivists. Therefore, the assertion that "... the psychology of the so-called recidivists and professionalcriminals is well known: the complete inefficiency for them of the threat of reprisal is an established fact" [5, p. 68], it is completely untenable and not justified. Position of Krylenko N.V. is also supported by Zelinskyi A.F., who believes that one of the prerequisites of the repeated crimes acts emotional deafness not only to attitude to other people but also to own fate that makes recidivists indifferent to threat of punishment [2, p. 44]. We can only talk about the degree of fear. The feeling of fear has an instinctively-biological basis and is inherent not only to humans, but also to animals. The fact that there are people who do not feel any fear at all should be understood in the sense that Adam would never have felt fear breaking the ban if he had remained just an animal. Therefore, an inability to be afraid is proof that the individual is either an animal or an angel, and both of them, also according to God's scriptures, are less perfect than a person.

Even in his time, C. Beccaria said: "Do you want to prevent a crime? ... Make people afraid of them and only them. Fear of the law is gracious!" [1, p. 151].

\section{References}

1. Beccaria Ch. O prestupleniyakh i nakazaniyakh [On crimes and punishments]. Moscow, Infra-M Publ., 2004, 184 p.

2. Zelinskyi A.F. Retsidiv prestupleniyi (struktura, svyazi, prognozirovanie) [Recidivism of crimes (structure, links, forecasting)]. Kharkov, Vischa shk. Publ., 1980, 152 p.

3. Kenon V. Fiziologiya emotsiyi: telesnye izmeneniya pri boli, golode, strakhe $i$ yarosti [Physiology of emotions: bodily changes with pain, hunger, fear and rage]. Leningrad, 1927, $175 \mathrm{p}$.

4. Korobeev A.I., Uss A.V., Golik Yu.V. Ugolovno-pravovaya politika [Criminal-legal policy]. Krasnoyarsk, Krasnoyarsk University Publ., 1991, 240 p.

5. Krylenko N.V. Sud i pravo v SSSR. Osnovy ugolovnogo material'nogo prava [Court and law in the USSR. Basis of criminal material law]. Moscow, 1930, part. 3, $179 \mathrm{p}$.

6. Piantkovskyi A.A. Uchenie Gegelya o prave i gosudarstve i ego ugolovno-pravovaya teoriya [Teaching of Hegel on law and state and its criminal-law theory]. Moscow, PAIMS Publ., 1993, $480 \mathrm{p}$.

7. Salnikov V.P. Sotsialisticheskaya pravovaya kul'tura. Metodologicheskie problemy [Socialistic legal culture. Methodological problems]. Saratov, Saratov University Publ., 1989, 144 p.

8. Sitkovskaya O.D. Psikhologiya ugolovnoyi otvetstvennosti [Psychology of criminal responsibility]. Moscow, NORMA Publ., 1998, 285 p.

9. Tugarinov V.P. Zakony obyektivnogo mira, ikh poznanie i primenenie [Laws of objective world, their cognition and application]. Leningrad, 1954, 195 p. 
DOI: 10.25108/2304-1730-1749.iolr.2019.61.112-117

УДК 343.9

Рагимов И.М.

Средства достижения цели наказания

Аннотация: Философия помогает решать ряд важнейших проблем, среди которых, прежде всего, стоит назвать вопросы о природе психического, об уровнях психического и концепции человека и личности. С чувством сожаления приходится констатировать, что юриспруденция на сегодняшний день не в полной мере использует результаты этих исследований применительно к области изучения причин преступного поведения человека. Что касается исследования проблем психического воздействия наказания на человека и механизма восприятия личностью самой угрозы, а также удерживающей роли наказания от противоправных действий субъекта деятельности, то они, практически, никогда не были объектом научного рассмотрения.

Угроза наказания имеет дело, скорее, с психологией людей. Поэтому, если бы психологи серьезно заинтересовались воздействием угрозы наказания на человека, это привело бы к важным практическим результатам. Речь идет об изучении психологической закономерности системы «человек - угроза наказания». Только таким образом мы сможем уяснить психологическое отношение к этой угрозе. Рассмотрение этого вопроса требует в очень краткой форме обратиться к науке - психологии, которая изучает закономерности и механизмы психической деятельности людей.

Ключевые слова: наказание; цель и функция; уголовная санкция; психология; причина преступного поведения; предупреждение.

\section{Библиография}

1. Беккариа Ч. О преступлениях и наказаниях. - М.: Инфра-М, 2004. - 184 с.

2. Зелинский А. Ф. Рецидив преступлений (структура, связи, прогнозирование). - Харьков: Вища шк., 1980. - 152 с.

3. Кенон В. Физиология эмоций: телесные изменения при боли, голоде, страхе и ярости. Л.: 1927. - 175 c.

4. Коробеев А.И., Усс А.В., Голик Ю.В. Уголовно-правовая политика. - Красноярск: Изд-во Краснояр. ун-та, 1991. - 240 с.

5. Крыленко Н.В. Суд и право в СССР. Основы уголовного материального права. - М.: 1930, ч. 3. - 179 с.

6. Пиантковский А. А. Учение Гегеля о праве и государстве и его уголовно- правовая теория. - М.: ПАИМС, 1993. - 480 с.

\footnotetext{
- Рагимов Ильгам Мамедгасан оглы - доктор юридических наук, профессор, заслуженный юрист Азербайджанской Республики, член Совета МОПИ, Азербайджан. E-mail: mopi_sid@yahoo.com
} 
7. Сальников В.П. Социалистическая правовая культура. Методологические проблемы / под ред. Матузова Н.И. - Саратов, Изд-во Сарат. ун-та, 1989. - 144 с.

8. Ситковская О.Д. Психология уголовной ответственности. - М.: НОРМА, 1998. - 285 с.

9. Тугаринов В. П. Законы объективного мира, их познание и применение. - Л.: 1954. $195 \mathrm{c}$. 